\title{
SCC in situ
}

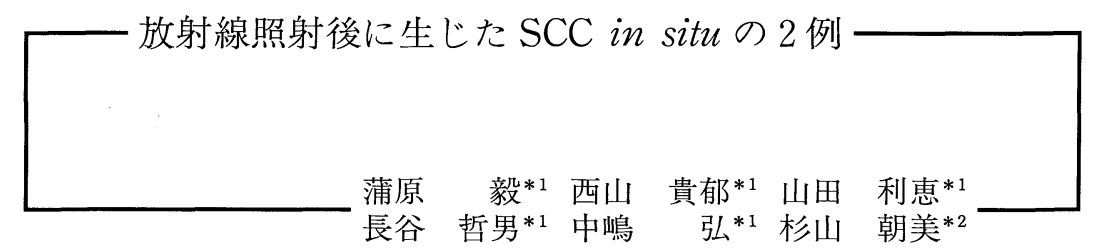

\section{Summary}

We report two cases with Squamous Cell Carcinoma (SCC) in situ caused by irradiation to hand eczemas, resisitant to any topical therapies.

Both of our cases clinically show palmer sclerosis and flexor restriction of the fingers, compatible to chronic radiation dermatitis. Although SCC arising in chronic radiation dermatitis is usually developed ten to twenty years after irradiation, in our cases SCC were found more than forty years after irradiation.

Key words : SCC, Irradiation, Hand eczema, P53

\section{はじめに}

皮膚科領域では，湿疹，尋常性乾癬などの難 治性皮膚良性疾患に対しても限界線などの低工 ネルギー放射線療法を広く行っていた時期があ った1)。今回我々は, 難治性の手湿疹に放射線照 射が行われ, 約 40 年後に SCC in situ が発症し た 2 例を経験したので報告する。

\section{症例}

症例 $1: 75$ 歳, 女性

初 診: 1997年 1 月23日

家族歴：父親が胃癌。

*1 Takeshi KAMBARA, Takafumi NISHIYAMA, Rie YAMADA, Tetuo NAGATANI, Hiroshi NAKAJIMA：横浜市立大学皮膚科学教室

*2 Asami SUGIYAMA：横浜栄共済病院
既往歴：特記すべきことなし。

現病歴：20歳頃より両手に難治性の手湿疹が 生じた。30歳頃から横須賀市の某医院で放射線 と紫外線を 2 週間に 1 回の割で約 1 年間照射を 受けた。その後, 照射部に徐々に角化, 硬化性 病変が生じ, 進行し, 平成 3 年横浜南共済病院 を受診した。平成 5 年頃より両手掌に潰瘍が出 現し, 平成 8 年12月同院で潰瘍部の生検を受け 有棘細胞癌と診断され, 平成 9 年 1 月 23 日, 当 科を紹介受診となった。

検査所見：へモグロビンが軽度低值 $(10.2 \mathrm{~g} /$ $\mathrm{d} l)$, トリグリセリドが軽度高值 $(295 \mathrm{mg} / \mathrm{d} l)$ で あったが，それ以外には特に異常は認められな かった。

現 症：両手掌は全体が硬化し手指の伸展制 限が認められた。左手掌には第 2 指中手指関節 部に瘷痕を伴う慢性放射線皮膚が認められた (図1a)。右母指丘には前回生検後の潰瘍が認め られた(図1b)。慢性放射線皮膚に続発した有棘 細胞癌と診断し平成 9 年 1 月 31 日腫瘍切除術, 


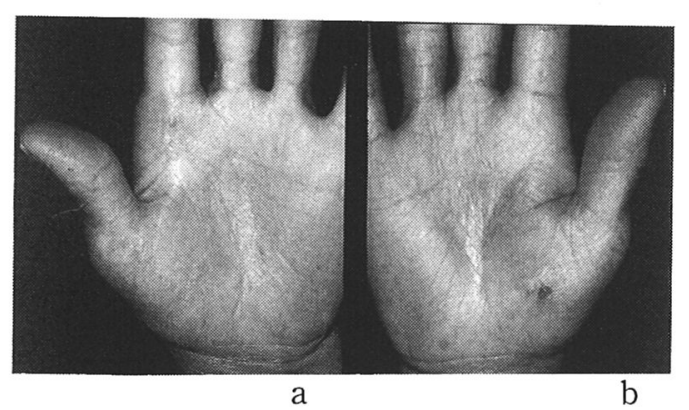

図 1。症例 1 , 初診時臨床像

a：左手掌第 2 指中手指関節部に㓔痕を伴う 紅斑を認める

b : 右手掌に過角化, 拘縮, 母指丘に前回生検 後の潰瘍を認める

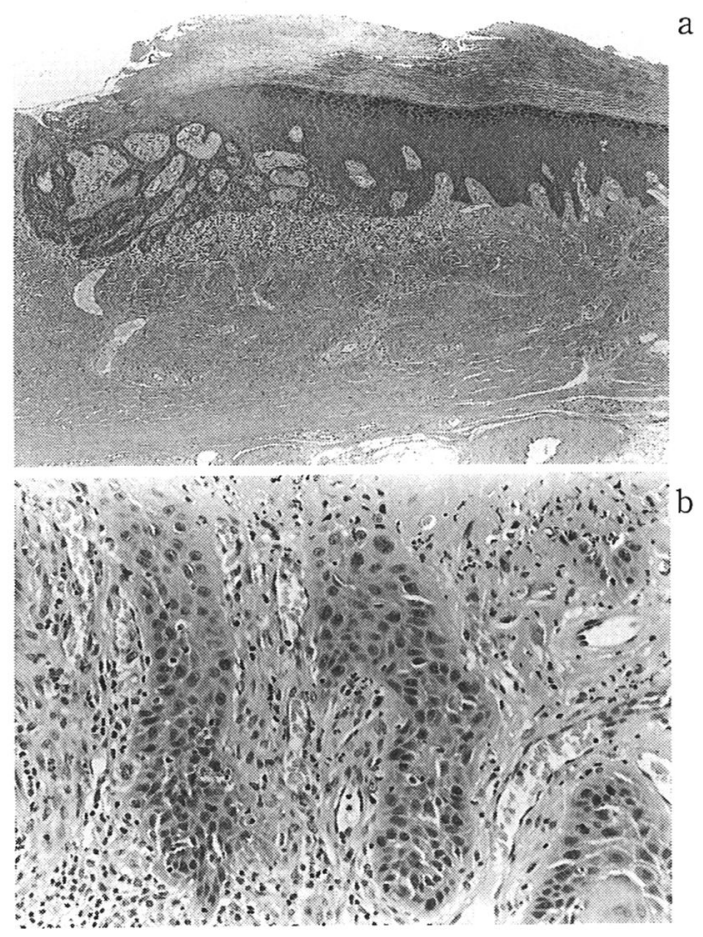

図 2.症例 1 , 病理組織像 (HE 染色)

a：弱拡大像 $(\times 20)$. 不全角化を伴う角質増 生, 表皮肥厚, 真皮浅層の炎症細胞浸潤と その下方での膠原線維の増生を認める

b : 強拡大像 $(\times 200)$. 表皮細胞の配列の乱れ と核の大小不同，クロマチンの濃縮を伴

う異形細胞の増殖を認める
分層植皮術を施行した。

病理組織学的所見：弱拡大像では不全角化を 伴う角質増生，表皮肥厚，表皮突起の延長，真 皮浅層の炎症細胞浸潤とその下方での膠原線維 の増生が認められた(図2a)。強拡大像では表皮 細胞の配列の乱れと核の大小不同，クロマチン の濃縮を伴う異形細胞の増殖が認められた (図2b)。以上より SCC in situ と診断した。

症例 $2: 74$ 歳, 女性

初 診：1992年12月 2 日

既往歴, 家族歴：特記すべきことなし。

現病歴：15歳頃より手湿疹と診断され，20歳 頃から手掌部に放射線照射を数回受けた。平成 4 年 5 月頃より右手掌にびらんが出現し市販の クリームを外用していたが改善しないため，平 成 4 年10月横浜栄共済病院を受診した。手掌の びらん部の生検により有棘細胞癌と診断され, 平成 4 年12月 2 日に当科を紹介受診となった。

検査所見：白血球 $(10800 / \mu l) ，$ LDH (512 $\mathrm{mU} / \mathrm{m} l)$ ，トリグリセリド $(245 \mathrm{mg} / \mathrm{d} l)$ の軽度 上昇が認められたが，その他には異常は認めら れなかった。

現 症：両手掌全体に厚い角化と皮膚の硬化 が認められ，右手掌中央には径 $1 \times 2 \mathrm{~cm}$ 大の 潰瘍が認められた(図 3 )。手指は拘縮していた。 放射線照射後に生じた有棘細胞癌と診断し，平 成 4 年12月11日腫瘍切除術, 植皮術を施行した。

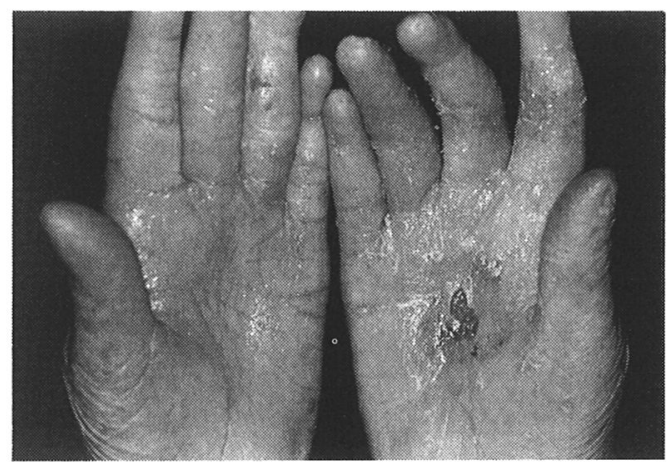

図 3. 症例 2, 初診時臨床像 両手掌は全体に硬化し，右手掌中央に径 $1 \times$ $2 \mathrm{~cm}$ の潰瘍を認める 
病理組織学的所見：弱拡大像では, 不全角化 を伴う著しい表皮肥厚が認められ，真皮浅層で の炎症細胞浸潤とその下方での膠原線維の増生 が認められた(図4a)。強拡大像では，表皮細胞 の配列の乱れ，核小体の目立つ腫大した核を持 つ異形細胞の増殖，核分裂像が認められた (図4b)。以上より SCC in situ と診断された。

\section{考察}

1990年より1997年 3 月までの 7 年間に当科を 受診した患者で有棘細胞癌と診断された62例の 前駆病変を図 5 に示した。日光角化症は26例と 最も多く, 次いで熱傷・電撃症痏痕が 6 例であ った。放射線照射後の発症した症例は 3 例であ

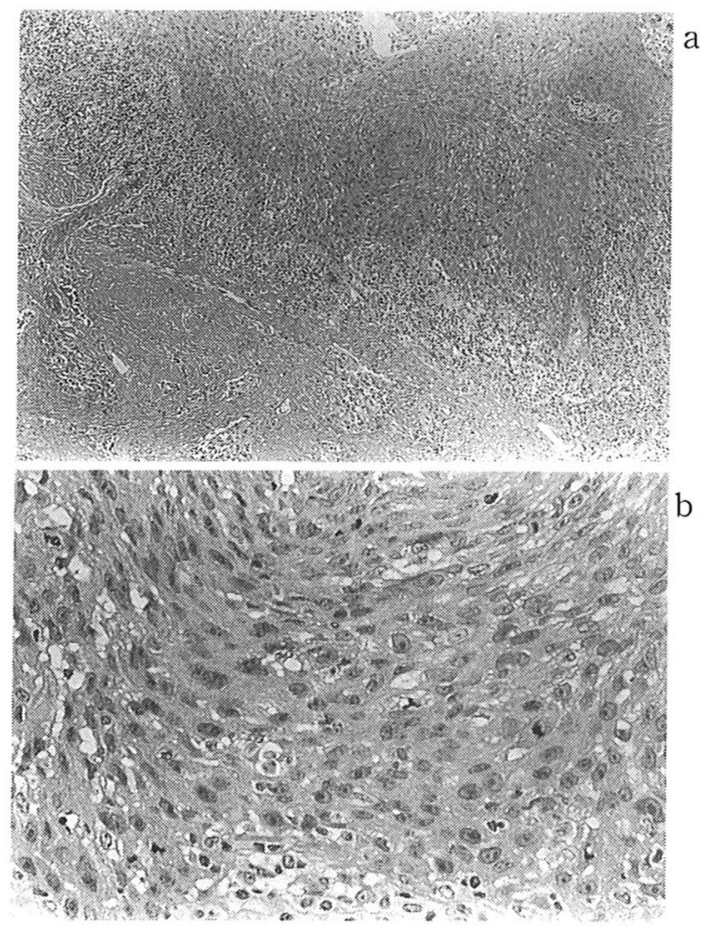

図 4.症例 2, 病理組織像 (HE 染色)

a : 弱拡大像 $(\times 20)$. 不全角化を伴う著しい 表皮肥厚, 真皮浅層の炎症細胞浸潤とそ の下方での膠原線維の增生を認める

b: 強拡大像 $(\times 200)$. 表皮細胞の配列の乱 れ，核小体の目立つ腫大した核を持つ異 形細胞の増殖を認める
つた。今回報告した 2 例は，いずれも難治性の 手湿疹に放射線を約 1 年間反復して照射された 症例であり，初診時でいずれも著しい角化，硬 化と手指の屈曲拘縮がみられ, 慢性放射線障害 に伴う変化と考えられた。放射線角化症は，一 般に少線量の放射線を長時間にわたり反覆照射 した場合に多いとされているが2)，今回の例も

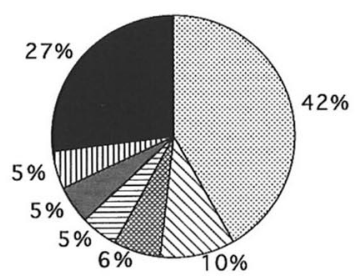

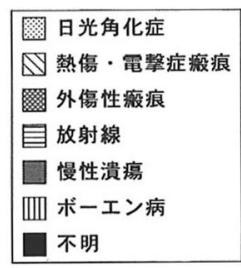

図 5. 横浜市立大学の有棘細胞癌の前駆病変 (19901997年)

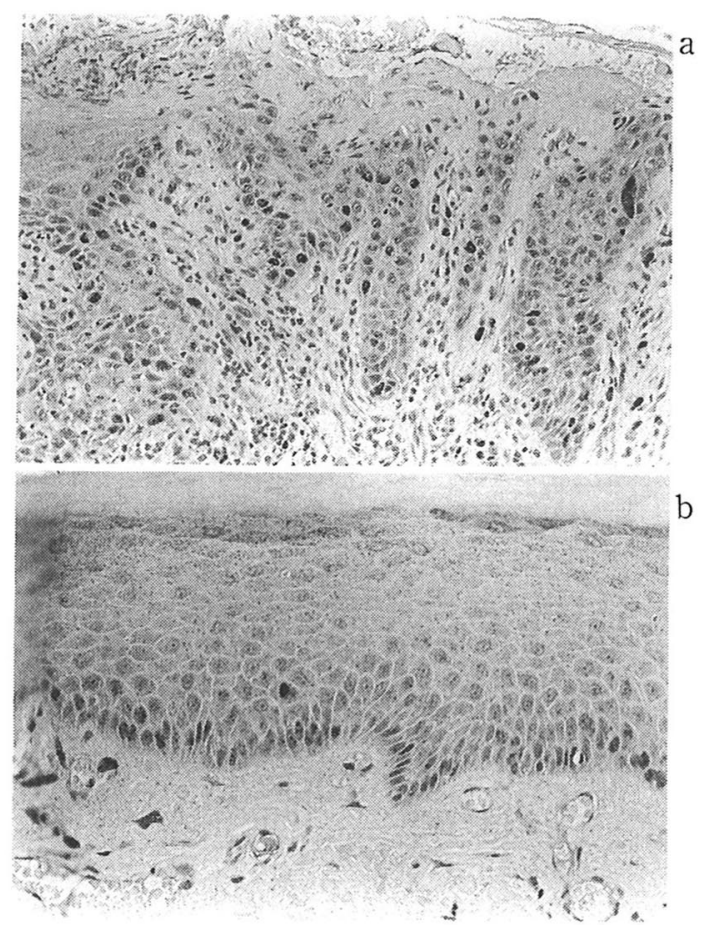

図 6. 免疫組織化学像 $(P 53$ 染色, $\times 50)$

a : 腫瘍部で P53の高発現を認める

b : 異型性を認めない部位でも P53の高発現 を認める 
これに一致していた。また，放射線照射後有棘 細胞癌が発生するまでの年数は, 照射後10年か ら20年で最も発生率が高いといわれている が2), 今回の例ではいずれも照射後 40 年近く, あ るいはそれ以上を経て発生したものであった。 紫外線による有棘細胞癌ではP 53 , rasの mutation が発癌過程に強く関与していること が報告されており ${ }^{3)}$, 本症例でも $\mathrm{P} 53$ の免疫染色 （DAKO-p53，DO-7）で，腫瘍部および異型性 の認められない周辺部でも P53の高発現が認め られた（図 6 )。従って，放射線発癌においても 紫外線発癌と同様の機序が働いているものと推 察された。最後に，著しい角化症あるいはびら ん潰瘍を呈する患者で難治性の場合には，放射
線照射の既往を問診すると同時に有棘細胞癌の 発症を疑い，生検すべきことを銘記すべきであ る。

\section{文献}

1) 岡崎美知治, 井上勝平, 緒方克巳: 本邦における 放射線皮膚西性腫瘍の統計。西日皮膚，44：824830, 1982 ,

2 ）石原和之, 早坂賢一, 亀谷徹：放射線角化症. 癌 の臨, $27 ： 937-941 ， 1981$.

3 ) Nagano, T., Ueda, M., Ichikawa, M. : Expression of p53 Protein is an Early Event in Ultraviolet Light-Induced Cutaneous Squamous Cell Carcinogenesis. Arch. Dermatol., 129: 11571161, 1993. 